\title{
Growth Hormone Augments Superoxide Anion Secretion of Human Neutrophils by Binding to the Prolactin Receptor
}

\author{
Yung-Kang Fu, ${ }^{\star}$ Sean Arkins, ${ }^{*}$ Germaine Fuh, ${ }^{\ddagger}$ Brian C. Cunningham, ${ }^{\ddagger}$ James A. Wells, ${ }^{\ddagger}$ \\ Sherman Fong," Michael J. Cronin," Robert Dantzer,' and Keith W. Kelley* \\ ${ }^{*}$ Laboratory of Immunophysiology, Department of Animal Sciences, University of Illinois, Urbana, Illinois 61801; ${ }^{\ddagger}$ Protein Engineering, \\ ${ }^{\S}$ Immunobiology, and "Endocrine Research Departments, Genentech Inc., South San Francisco, California 94080; and \\ 'INRA-INSERM, Unité de Recherches de Neurobiologie des Comportements, U 176, 33077 Bordeaux, France
}

\begin{abstract}
Recombinant human growth hormone (HuGH) and human prolactin (HuPRL), but not $\mathrm{GH}$ of bovine or porcine origin, prime human neutrophils for enhanced superoxide anion $\left(\mathrm{O}_{2}^{-}\right)$secretion. Since HuGH, but not GH of other species, effectively binds to the HuPRL receptor (HuPRL-R), we used a group of HuGH variants created by site-directed mutagenesis to identify the receptor on human neutrophils responsible for $\mathbf{H u G H}$ priming. A monoclonal antibody (MAb) directed against the HuPRL-R completely abrogated $\mathrm{O}_{2}^{-}$secretion by neutrophils incubated with either HuGH or HuPRL, whereas a MAb to the HuGH-R had no effect. The HuGH variant K172A/F176A, which has reduced affinity for both the HuGH-binding protein (BP) and the HuPRL-BP, was unable to prime human neutrophils. This indicates that priming is initiated by a ligand-receptor interaction, the affinity of which is near that defined for receptors for PRL and GH. Another HuGH variant, K168A/ E174A, which has relatively low affinity for the HuPRL-BP but slightly increased affinity for the HuGH-BP, had much reduced ability to prime neutrophils. In contrast, HuGH variant E56D/R64M, which has a similar affinity as wild-type HuGH for the HuPRL-BP but a lower affinity for the HuGHBP, primed neutrophils as effectively as the wild-type $\mathrm{HuGH}$. Finally, binding of HuGH to the HuPRL-BP but not to the HuGH-BP has been shown to be zinc dependent, and priming of neutrophils by HuGH was also responsive to zinc. Collectively, these data directly couple the binding of HuGH to the HuPRL-R with one aspect of functional activation of human target cells. (J. Clin. Invest. 1992. 89:451-457.) Key words: prolactin receptors $\bullet$ respiratory burst $\bullet$ somatotropin
\end{abstract}

\section{Introduction}

After binding to cellular membrane receptors, growth hormone $(\mathrm{GH})^{1}$ promotes growth and differentiation of a variety of cell types (1-3), including hemopoietic tissue (4-6). Human

\footnotetext{
Address reprint requests to Dr. Keith W. Kelley, Laboratory of Immunophysiology, Department of Animal Sciences, University of Illinois, 1201 West Gregory Drive, Urbana, IL 61801.

Received for publication 7 August 1991.
}

1. Abbreviations used in this paper: $\mathrm{BP}$, binding protein; $\mathrm{GH}$, growth hormone; HuGH, human growth hormone; HuGH-R, human growth hormone receptor; HuIGF-I, human insulin-like growth factor I; HuIGF-I-R, human insulin-like growth factor-I receptor; PL, placental lactogen; PRL, prolactin (similarly, HuPRL and HuPRL-R, human prolactin and human prolactin receptor); $\mathrm{rBoGH}$, recombinant bovine growth hormone; $\mathrm{rPoGH}$, recombinant porcine growth hormone.

J. Clin. Invest.

(C) The American Society for Clinical Investigation, Inc.

$0021-9738 / 92 / 02 / 0451 / 07 \quad \$ 2.00$

Volume 89, February 1992, 451-457
$\mathrm{GH}(\mathrm{HuGH})$, but not $\mathrm{GH}$ of other species $(7,8)$, has a pleiotropic receptor-binding capacity (1). Indeed, many of the biological effects of $\mathrm{HuGH}$ are shared with prolactin (PRL) because $\mathrm{HuGH}$ can bind and activate both somatogenic and lactogenic receptors. The lactogenic receptor-mediated effects, such as enhanced thymulin production by rat thymic epithelial cells, can occur via binding of $\mathrm{HuGH}$ to the rat PRL receptor (PRL-R) (9). In contrast, human PRL (HuPRL) binds only to the lactogenic receptor and does not bind to the somatogenic receptor $(7,8)$.

The mechanism by which HuGH exerts its pleiotropic effects has not been well defined beyond the level of interaction with a surface receptor (1). Among those homologous receptors to which $\mathrm{HuGH}$ can bind, only two have been cloned, the HuGH-R $(10,11)$ and the HuPRL-R $(12,13)$, although there are likely to be others such as the receptor for placental lactogen (14). HuGH residues which are critical for binding to either the HuGH-R or HuPRL-R have been identified by analyzing segment-substituted and single residue-substituted $\mathrm{HuGH}$ variants, produced by site-directed mutagenesis techniques, with a competitive binding assay using the extracellular binding proteins derived from the receptors (15-18). Additionally, the variants were used to demonstrate that zinc mediates binding of HuGH to the HuPRL-R (15). Three amino acids of the HuGH molecule, residues 18 (His), 21 (His), and $174(\mathrm{Glu})$, coordinate with residue 188 (His) of the HuPRL-R to form the four zinc ligands. These zinc ligands appear to be critical for determining the binding preference of $\mathrm{HuGH}$ because mutants that alter these positions (15) bind preferentially to somatogenic rather than to lactogenic receptors (18).

$\mathrm{GH}$ is now recognized to regulate both the differentiation and activation of lymphoid and myeloid cells (5). We have demonstrated that $\mathrm{GH}$ increases the resistance of rats to Salmonella typhimurium by increasing the ability of macrophages to kill $S$. typhimurium (19) and to secrete tumor necrosis factor- $\alpha$ (20). GH also augments the capacity of both macrophages (21, 22) and neutrophils (23) to secrete $\mathrm{O}_{2}^{-}$in response to triggering stimuli such as opsonized-zymosan, formylmethionyl-leucylphenylalanine (FMLP) and phorbol myristate acetate (PMA). In the present report, we used the model of human neutrophils that were primed with $\mathrm{HuGH}$, HuPRL, or HuGH variants, in conjunction with monoclonal antibodies (MAbs) against either HuGH-R or HuPRL-R, to determine which receptor is responsible for augmenting the secretion of $\mathrm{O}_{2}^{-}$after stimulation of human neutrophils with PMA. Based on four distinct lines of evidence, we demonstrate that the HuPRL-R can account for the HuGH-mediated priming of human neutrophils for an enhanced respiratory burst.

\section{Methods}

$H u G H$ variant preparation and binding studies. HuGH variants were prepared by site-directed mutagenesis, purified, and analyzed for their 
binding affinity for the HuGH- or HuPRL-binding protein (BP) as described $(17,18)$. The binding affinities of HuGH variants that were designed to discriminate between the HuGH-R and HuPRL-R are described in Table I.

Neutrophil isolation. Heparinized human venous blood was collected from healthy, 20-35-yr-old volunteers. Whole blood was gently mixed with an equal volume of $3 \%$ dextran (T500, Pharmacia LKB Biotechnology, Inc., Piscataway, NJ). The dextran solution was prepared in HBSS (without $\mathrm{Ca}^{++}, \mathrm{Mg}^{++}$, or phenol red; Gibco Laboratories, Grand Island, NY). The suspension was allowed to settle for 30 min at room temperature. The leukocyte-rich plasma was collected from the upper portion of the suspension and carefully layered onto Ficollpaque (density 1.077, Pharmacia LKB Biotechnology, Inc.). The gradient was centrifuged at $500 \mathrm{~g}, 20^{\circ} \mathrm{C}$ for $35 \mathrm{~min}$. The supernatant, including platelets and the mononuclear leukocyte-rich fraction, was removed and the erythrocyte and neutrophil-rich pellet was resuspended with $0.2 \%$ saline and was then immediately brought up to isotonicity with an equal volume of $1.6 \%$ saline. Neutrophils were washed once by centrifugation and finally resuspended with HBSS. Whole blood yielded $3-5 \times 10^{6}$ cells $/ \mathrm{ml}$, consisting of $>95 \%$ neutrophils as determined by Wright Giemsa differential staining and with a viability $>99 \%$ assessed by trypan blue exclusion.

Porcine neutrophils were isolated from venous blood as described (23). Bovine neutrophils were isolated according to the protocol of Carlson and Kaneko (24). Briefly, heparinized bovine blood was diluted $1: 1$ with $\mathrm{HBSS}$ and centrifuged at $500 \mathrm{~g}, 20^{\circ} \mathrm{C}$ for $35 \mathrm{~min}$. After removal of plasma and buffy coat, the pellet was resuspended with $0.2 \%$ saline to lyse erythrocytes and was immediately reconstituted to isotonicity with an equal volume of $1.6 \%$ saline. After the second lysis, neutrophils were washed and resuspended in HBSS.

Priming of neutrophils. Neutrophils were maintained in a serumfree suspension in HBSS during the course of treatment (23). Each milliliter of the treatment mixture contained $5 \times 10^{6}$ neutrophils and the following reagents in HBSS: recombinant bovine $\mathrm{GH}$ ( $\mathrm{rBoGH}$; a gift from Dr. Emerson Potter, Lilly Research Laboratories, Greenfield, IN), recombinant porcine GH ( $\mathrm{rPoGH}$; a gift from Dr. Bosco Wang, American Cyanamid Co., Princeton, NJ), recombinant human insulin-like growth factor I (rHuIGF-I; IMCERA Bioproducts, Inc., Terre Haute, IN), rHuPRL (16), rHuGH wild type (Genentech, Inc., S. San Francisco, CA), or HuGH variants $(17,18)$. Cells were incubated at $37^{\circ} \mathrm{C}, 5 \% \mathrm{CO}_{2}$, for 3-4 $\mathrm{h}$ with gentle periodic agitation. The effect of a MAb to HuPRL-R or to the HuGH-R on priming of neutrophils mediated by either HuPRL or HuGH was studied by preincubating neutrophils with these MAbs at $37^{\circ} \mathrm{C}$ for $1 \mathrm{~h}$ before the addition of $\mathrm{HuGH}$ or HuPRL. The anti-HuGH-R MAb (MAb5, 25) was purchased from Agen Biomedical, Ltd. (Parsippany, NJ), anti-HuIGF-I-R MAb ( $\alpha$ IR3) was obtained from Oncogene Science, Inc. (Manhasset, NY), and anti-HuPRL-R MAb (9D11) was kindly provided by Brian Fendley at Genentech, Inc., after purification from mouse ascitic fluid on protein A sepharose. All three of these MAbs were derived from murine hybridomas, were of the $\mathrm{IgG}_{1}$ isotype, and were free of preservatives. In experiments testing the effect of exogenous zinc on priming of neutrophils, $\mathrm{ZnCl}_{2}$ was added to a mixture of cells incubated with either HuGH or HuPRL.

Measurement of superoxide anion production. $\mathrm{O}_{2}^{-}$was measured by the superoxide dismutase (SOD)-inhibitable reduction of ferricytochrome $c$ (26) as described previously (23). Briefly, a response spectrophotometer (Gilford Instrument Laboratories, Inc., Oberlin, $\mathrm{OH}$ ) equipped with a thermostatic chamber $\left(37^{\circ} \mathrm{C}\right)$ capable of reading six cuvettes was used. Each cuvette contained a reaction mixture of $1 \mathrm{ml}$ with $2 \times 10^{6}$ neutrophils, $80 \mu \mathrm{M}$ cytochrome $c$ (type III, Sigma Chemical Co., St. Louis, MO), and 100 ng PMA (LC Service Co., Woburn, MA). The reference cuvette contained an additional $75 \mu \mathrm{g}$ of SOD (Sigma Chemical Co.). Reduction of cytochrome $c$ was measured continuously at $550 \mathrm{~nm}$ (with a band width of $0.5 \mathrm{~nm}$ ) after addition of PMA. The amount of $\mathrm{O}_{2}^{-}$production in a period of $10 \mathrm{~min}$ was calculated based on the extinction coefficient of cytochrome $c$ of 21 $\mathrm{mM}^{-1} \mathrm{~cm}^{-1}$. Results are shown as the mean $(n=3) \pm$ SEM of PMA-triggered $\mathrm{O}_{2}^{-}$production by $2 \times 10^{6}$ neutrophils in $10 \mathrm{~min}$.

$\mathrm{Nb} 2$ cell proliferation assay. The rat lymphoma cell line, $\mathrm{Nb} 2$ (27), was maintained in suspension cultures in Fischer's medium (Gibco Laboratories) supplemented with horse serum (10\%, Pel-Freez Biologicals, Rogers, AR), fetal calf serum (FCS, 10\%, Hyclone Labs., Inc., Logan, UT), 2-mercaptoethanol $\left(10^{-4} \mathrm{M}\right.$, Sigma Chemical Co.), penicillin $(50 \mathrm{U} / \mathrm{ml})$, and streptomycin $(50 \mu \mathrm{g} / \mathrm{ml})$ in an atmosphere of $5 \%$ $\mathrm{CO}_{2}$ at $37^{\circ} \mathrm{C}$. Approximately $24 \mathrm{~h}$ before the $\mathrm{Nb} 2$ cells were used in the proliferation assay, they were transferred to Fischer's medium supplemented as above but containing only $0.5 \%$ FCS and $5 \%$ horse serum. At the end of this preincubation, cells were washed once by centrifugation $(10 \mathrm{~min}$ at $300 \mathrm{~g}$ ) and resuspended in Fischer's medium supplemented only with 2-mercaptoethanol and antibiotics. Cells were distributed in 96-well plates ( $100 \mu \mathrm{l}, 2 \times 10^{5}$ cells per well) in triplicate cultures and then $100 \mu \mathrm{l}$ of each treatment (diluted in the same medium) was added to each well. The cells were incubated for $24 \mathrm{~h}$ and pulsed with $1 \mu$ Ci per well of tritiated thymidine $\left(\left[{ }^{3} \mathrm{H}\right] \mathrm{TdR} ; 6.7 \mathrm{Ci} / \mathrm{mmol} ; \mathrm{ICN}\right.$, Irvine, CA) in $25 \mu$ l of Fischer's medium for $6 \mathrm{~h}$. Cells were harvested: onto glass microfiber filter (Whatman, Inc., Clifton, NJ) with a 24channel cell harvester (Cambridge Technology, Cambridge, MA). Filter discs were then dried in scintillation vials. To each vial, $3 \mathrm{ml}$ of Omnifluor scintillation cocktail (Dupont-New England Nuclear, Boston, MA) was added and $\left[{ }^{3} \mathrm{H}\right] \mathrm{TdR}$ incorporation was determined with a model LS 5801 liquid scintillation counter (Beckman Instruments, Inc., Fullerton, CA) and expressed as counts per minute.

Statistical analysis. Duncan's multiple-range test was used to determine the differences between treatments and all data were analyzed using a general linear model (28).

\section{Results}

HuGH and HuPRL, but not PoGH or BoGH, prime human neutrophils for $\mathrm{O}_{2}^{-}$secretion. We recently reported that human and porcine neutrophils can be primed with recombinant

Table I. Binding of HuGH Wild-Type (WT) and Variants to the HuGH-or HuPRL-Binding Protein (HuGH-BP or HuPRL-BP)

\begin{tabular}{|c|c|c|c|c|c|}
\hline & \multicolumn{2}{|c|}{ HuPRL-BP } & \multicolumn{2}{|c|}{ HuGH-BP } & \multirow{2}{*}{$\begin{array}{c}\text { Change in } \\
\text { binding preference: } \\
\text { HuPRL-BP } \\
\text { HuGH-BP }\end{array}$} \\
\hline & $K_{\mathrm{D}}$ & $\frac{K_{\mathrm{D}}(\text { variant })}{K_{\mathrm{D}}(\mathrm{WT})}$ & $K_{\mathrm{D}}$ & $\frac{K_{\mathrm{D}}(\text { variant })}{K_{\mathrm{D}}(\mathrm{WT})}$ & \\
\hline & $p M$ & & $p M$ & & \\
\hline HuGHWT* & $38 \pm 3$ & (1) & $440 \pm 40$ & (1) & (1) \\
\hline $\mathrm{K} 172 \mathrm{~A} / \mathrm{F} 176 \mathrm{~A}^{*}$ & $320,000 \pm 70,000$ & 8,400 & $260,000 \pm 130,000$ & 560 & 15 \\
\hline K168A/E174A* & $350,000 \pm 80,000$ & 9,100 & $120 \pm 10$ & 0.27 & 34,000 \\
\hline $\mathrm{E} 56 \mathrm{D} / \mathrm{R} 64 \mathrm{M}^{* \ddagger}$ & $70 \pm 14$ & 2.1 & $10,000 \pm 2,000$ & 30 & 0.07 \\
\hline
\end{tabular}

* From Cunningham and Wells (20).

‡ From Cunningham et al. (17). 
$\mathrm{HuGH}$ or $\mathrm{PoGH}$, respectively, for enhanced $\mathrm{O}_{2}^{-}$secretion in response to PMA stimulation (23). This GH-induced priming was dose-dependent and the minimum dose required to detect significant enhancement of $\mathrm{O}_{2}^{-}$secretion was $\sim 100 \mathrm{ng} / \mathrm{ml}$. Subsequently, we tested the priming capacity of another human pituitary hormone, recombinant PRL, on human neutrophil $\mathrm{O}_{2}^{-}$secretion. A similar priming capacity of HuPRL was observed, but only half as much HuPRL $(50 \mathrm{ng} / \mathrm{ml})$ was required to significantly prime human neutrophils for enhanced $\mathrm{O}_{2}^{-}$secretion (data not shown). At a higher dose $(250 \mathrm{ng} / \mathrm{ml})$, both $\mathrm{HuPRL}$ and $\mathrm{HuGH}$ potently enhanced $\mathrm{O}_{2}^{-}$production by human neutrophils $(P<0.01$; Fig. 1). However, GH of other species (porcine and bovine) that does not bind to the PRL-R (13) but bind, albeit poorly, to the HuGH-R $(\sim 1,000$-fold less than $\mathrm{HuGH} ; 29$ ), failed to prime human neutrophils even at $10,000 \mathrm{ng} / \mathrm{ml}$. Both $\mathrm{rPoGH}$ and $\mathrm{rBoGH}$ showed dose-dependent activity in augmenting the secretion of $\mathrm{O}_{2}^{-}$by PMA-triggered neutrophils from pigs and cows, respectively (Fig. 2). These results are in agreement with our previous findings (23) and further indicate that priming of neutrophils for $\mathrm{O}_{2}^{-}$secretion by $\mathrm{GH}$ is conserved in a variety of species and that both the GH-R and PRL-R may be involved in this activation.

HuGH-mediated priming can be abrogated by a MAb against the HuPRL-R. Both HuGH- and HuPRL-mediated priming $\left(250 \mathrm{ng} / \mathrm{ml}\right.$ each) of human neutrophils for $\mathrm{O}_{2}^{-}$secretion were virtually abolished by a MAb (9D11, $500 \mathrm{ng} / \mathrm{ml}$ ) against the HuPRL-R $(P<0.01$, Fig. 3, top $)$. This same MAb was able to block the binding of HuGH to the extracellular domain of HuPRL-R in an ELISA format (G. Fuh, unpublished observation). However, another murine MAb (MAb5) of the same isotype and concentration $(500 \mathrm{ng} / \mathrm{ml})$ that binds on Western blots to the extracellular domain of the HuGH-R and has been shown to inhibit dimerization of HuGH-R (B. C. Cunningham, unpublished findings) did not substantially antagonize priming by either hormone. Neither of the MAbs affected $\mathrm{O}_{2}^{-}$secretion by control neutrophils that were incubated with medium only. These two MAbs did not show cross-reactivity with each other's receptors and purified BPs were able to absorb only the respective MAb, as assessed by Western blots

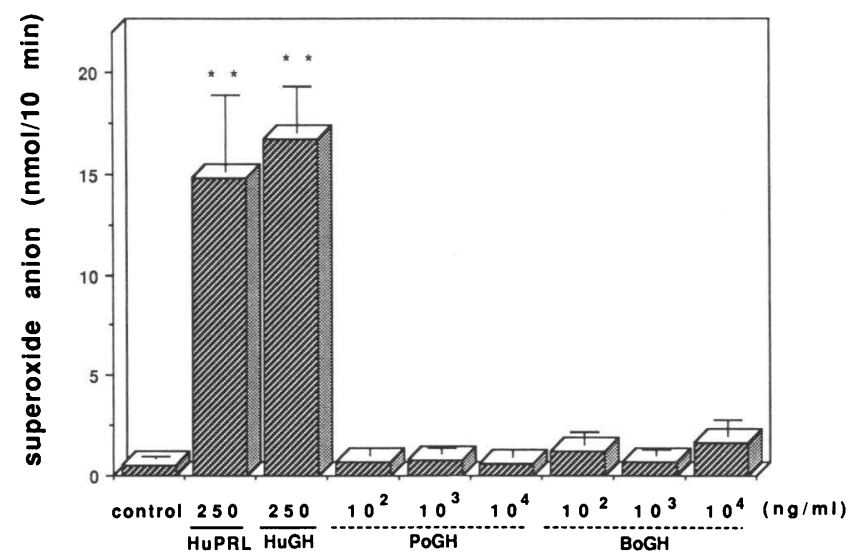

Figure 1. Human neutrophils are primed for $\mathrm{O}_{2}^{-}$secretion by recombinant $\mathrm{HuGH}$ or HuPRL but not by either recombinant PoGH or BoGH. Significant enhancement of $\mathrm{O}_{2}^{-}$production by human neutrophils preincubated with $\mathrm{HuGH}$ or HuPRL (each at $250 \mathrm{ng} / \mathrm{ml}$ ) is indicated by ${ }^{* *}(P<0.01)$. Neither recombinant PoGH nor BoGH was able to prime human neutrophils, even at $10^{4} \mathrm{ng} / \mathrm{ml}$. Results are expressed as the mean $\pm \operatorname{SEM}(n=3)$.

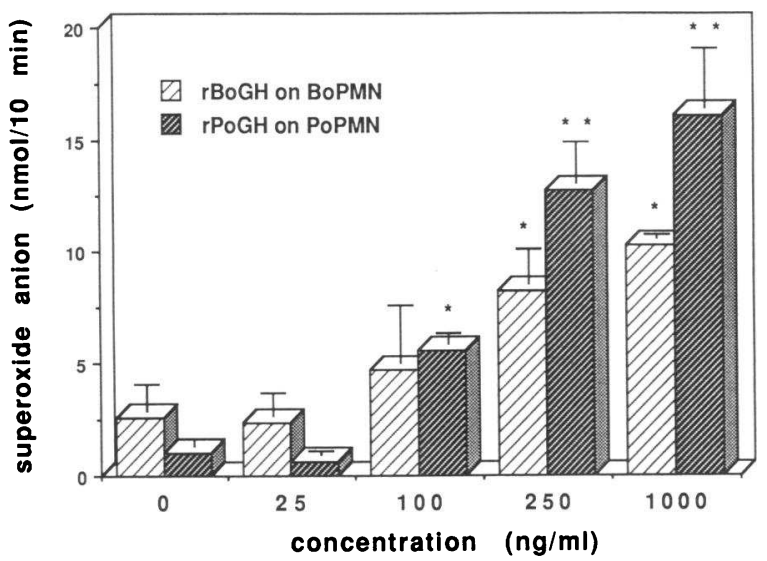

Figure 2. Recombinant $\mathrm{BoGH}$ or $\mathrm{PoGH}$ augments $\mathrm{O}_{2}^{-}$secretion by neutrophils of bovine $(n=3)$ or porcine $(n=3)$ origin, respectively, in a dose-dependent fashion. Significant enhancement of $\mathrm{O}_{2}^{-}$secretion is indicated by ${ }^{*}(P<0.05)$ or ${ }^{* *}(P<0.01)$.

(data not shown). In this same experiment, an equivalent amount of anti-HuIGF-I-R MAb was used as a control, isotype-matched antibody to demonstrate specificity of the antiHuPRL-R MAb inhibition of both HuGH- and HuPRL-mediated priming. HuIGF-I $(125 \mathrm{ng} / \mathrm{ml})$ can induce similar priming of human neutrophils for $\mathrm{O}_{2}^{-}$secretion, as described previously (23) and demonstrated in Fig. 3, bottom. Another murine MAb that had an identical isotype, anti-HuIGF-I-R $(\alpha \mathrm{IR} 3,500 \mathrm{ng} / \mathrm{ml})$, abrogated the HuIGF-I-mediated enhancement of $\mathrm{O}_{2}^{-}$secretion by neutrophils $(P<0.01)$ but not the priming mediated by HuGH or HuPRL. However, the antiHuPRL-R MAb, at the same concentration used in Fig. 3, top, could not block HuIGF-I-mediated priming of neutrophils, indicating that these MAbs are specific for their respective ligands. These results strongly suggest that the HuPRL-R is responsible for most of the priming induced by $\mathrm{HuGH}$.

Priming of human neutrophils for enhanced $\mathrm{O}_{2}^{-}$secretion with $\mathrm{HuGH}$ variants. A group of variants that were created by site-directed mutagenesis were designed to discriminate between binding to either the HuGH-BP or HuPRL-BP (Table I; $17,18)$. We tested these variants for their functional capacity to prime human neutrophils for $\mathrm{O}_{2}^{-}$secretion in comparison with wild-type HuGH (Fig. 4). Recombinant HuGH wild type, at 250 and $2,500 \mathrm{ng} / \mathrm{ml}$, primed neutrophils significantly $(P$ $<0.01$ ). HuGH variant, K172A/F176A, which has decreased binding affinity for both HuGH-BP and HuPRL-BP, did not prime these cells even at $2,500 \mathrm{ng} / \mathrm{ml}$. This result indicates that a ligand-receptor interaction whose epitope is similar to the $\mathrm{GH}$ or PRL receptor site is required for GH to augment the secretion of $\mathrm{O}_{2}^{-}$by human neutrophils. The $\mathrm{HuGH}$ variant $\mathrm{K} 168 \mathrm{~A} / \mathrm{E} 174 \mathrm{~A}$, which has a 34,000-fold greater preference for binding the HuGH-BP than the HuPRL-BP, did not prime neutrophils for significantly enhanced $\mathrm{O}_{2}^{-}$secretion. In contrast, the variant E56D/R64M, which has a 30 -fold reduction in affinity for the HuGH-BP and a marginally lower affinity for the HuPRL-BP (an 14-fold increase in preference for the HuPRL-BP), primed neutrophils for enhanced $\mathrm{O}_{2}^{-}$secretion as effectively as the wild-type $\mathrm{HuGH}$. These data strongly support the possibility that HuGH-mediated priming of human neutrophils for $\mathrm{O}_{2}^{-}$secretion is mostly mediated by binding to the HuPRL-R rather than to the HuGH-R. 

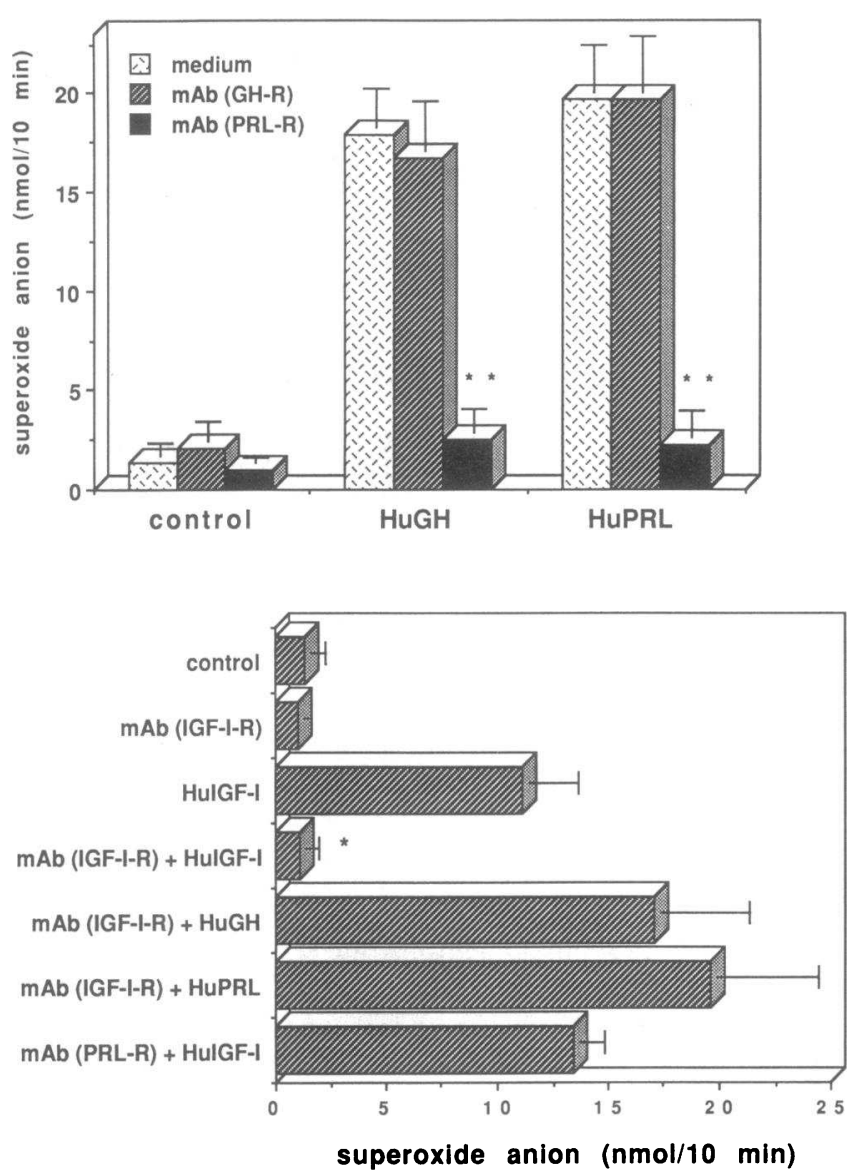

Figure 3. Top: A MAb against the HuPRL-R completely abrogates the priming of human neutrophils by $\mathrm{HuGH}$ or by HuPRL (each at 250 $\mathrm{ng} / \mathrm{ml}$ ) for $\mathrm{O}_{2}^{-}$secretion (as indicated by ${ }^{* *}, P<0.01 ; n=3$ ). A MAb directed against the HuGH-R, however, did not block the enhanced $\mathrm{O}_{2}^{-}$secretion by either reagent. Human neutrophils were preincubated with either control medium or MAb $(500 \mathrm{ng} / \mathrm{ml}$ each) for $1 \mathrm{~h}$ before addition of priming reagents. Both MAbs were identical in their species and isotype. There was no effect of these MAbs on $\mathrm{O}_{2}^{-}$secretion by neutrophils incubated with medium only (controls). Bottom: Additional control treatments conducted in these same experiments that demonstrate specific blocking of $\mathrm{HuGH}$-mediated priming by the HuPRL-R MAb are shown in the upper panel. Recombinant HuIGF-I $(125 \mathrm{ng} / \mathrm{ml})$ primed human neutrophils for $\mathrm{O}_{2}^{-}$secretion, and this priming was abrogated (indicated by ${ }^{* *}, P<0.01$ ) by a MAb against the HuIGF-I-R $(500 \mathrm{ng} / \mathrm{ml}$, same species and isotype as antiHuPRL-R), as recently reported (23). However, this anti-IGF-I-R isotype-specific MAb did not affect the priming mediated by either HuGH or HuPRL. The anti-HuPRL-R MAb did not affect the HuIGF-I-mediated enhancement of $\mathrm{O}_{2}^{-}$secretion.

Analysis of the biological activity of $\mathrm{HuGH}$ variants by the $\mathrm{Nb} 2$ lymphoma proliferation assay. One possible explanation for the lack of priming activity exhibited by variants K172A/ F176A and K168A/E174A might be the loss of their biological activity owing to disturbances in secondary and tertiary structures of these molecules. To address this issue, we tested the biological activity of these HuGH variants, along with both positive (FCS, HuGH, and HuPRL) and negative (HuIGF-I) controls using a highly sensitive assay which detects PRL-Rdependent stimulation of $\mathrm{Nb} 2$ cell proliferation at a level of PRL as low as $10 \mathrm{pg} / \mathrm{ml}$ (27). As shown in Fig. 5, the rat lymphoma cell line $\mathrm{Nb} 2$ proliferated in response to PRL-containing FCS (at concentrations of $1 \%$ and $10 \%$ ), but did not re-

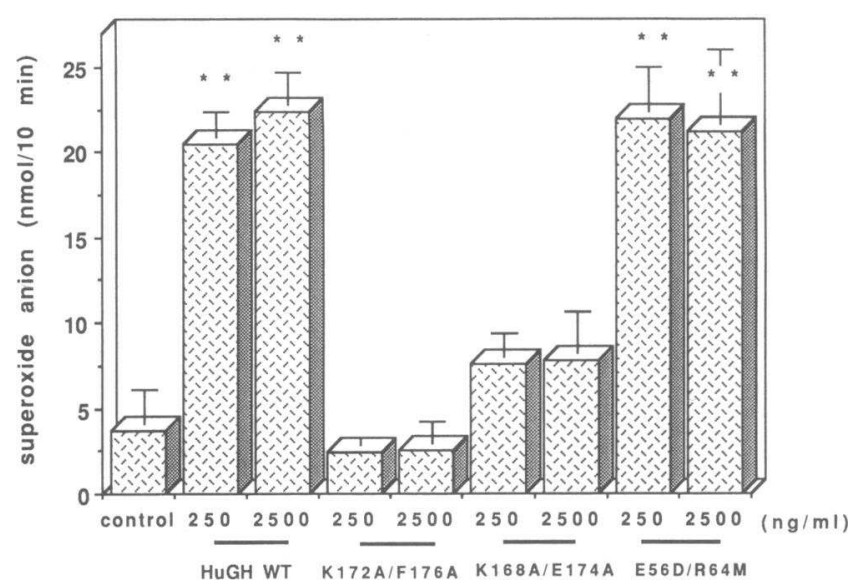

Figure 4. Priming of human neutrophils for $\mathrm{O}_{2}^{-}$secretion by $\mathrm{HuGH}$ variants that were created by site-directed mutagenesis. Significant enhancement of $\mathrm{O}_{2}^{-}$production (indicated by ${ }^{* *}, P<0.01 ; n=3$ ) above neutrophils incubated with medium alone (control) was observed in neutrophils treated with $\mathrm{HuGH}$ wild type (WT) and the variant E56D/R64M, which binds to the HuPRL-R. HuGH variant K172A/F176A, which does not effectively bind to either the HuGH-R or HuPRL-R, and the variant K168A/E174A, which binds effectively to only the $\mathrm{HuGH}-\mathrm{R}$, did not significantly augment $\mathrm{O}_{2}^{-}$secretion even at $2,500 \mathrm{ng} / \mathrm{ml}$.

spond to recombinant HuIGF-I. The lack of stimulation with HuIGF-I implies that the response of $\mathrm{Nb} 2$ cells is not stimulated by other growth-promoting factors, since IGF-I is highly conserved throughout many different species and is commonly used as a culture supplement for growing various cell lines (30). Both wild type HuGH and the variant E56D/R64M, which retains affinity for the PRL-BP, stimulated $\mathrm{Nb} 2$ proliferation as effectively as HuPRL. At the lowest dose tested $(0.1 \mathrm{ng} / \mathrm{ml})$,

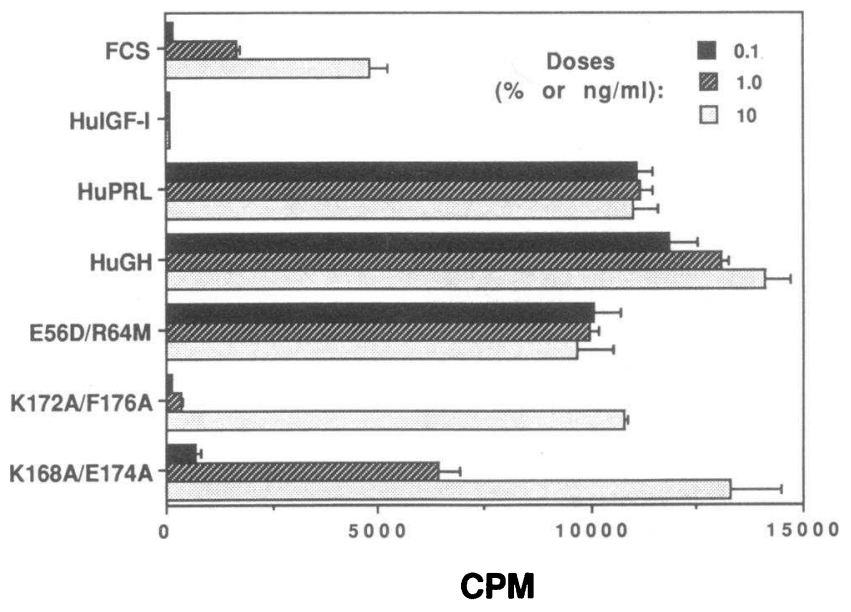

Figure 5. Assessment of the biological activity of $\mathrm{HuGH}$ variants as measured by their capacity to stimulate $\mathrm{Nb} 2$ cells to incorporate $\left[{ }^{3} \mathrm{H}\right]-$ TdR. FCS was used as a positive control, which showed a dose-dependent stimulation of $\mathrm{Nb} 2$ cell proliferation $(P<0.05$ at $1 \%$ and $P$ $<0.01$ at $10 \%$ ). HuIGF-I was used as a negative control to show the specificity of this assay. Significant proliferation of $\mathrm{Nb} 2$ cells $(P$ $<0.01$ ) was detected at concentrations of $0.1 \mathrm{ng} / \mathrm{ml}$ and greater of HuPRL, HuGH wild type, or variant E56D/R64M, while 1 and 10 $\mathrm{ng} / \mathrm{ml}$ were required for significant $(P<0.01)$ stimulation of $\mathrm{Nb} 2$ cells with variants K168A/E174A or K172A/F176A. Results are expressed as the mean $\pm \mathrm{SEM}$ of triplicate cultures. 
the other two HuGH variants, K168A/E174A and K172A/ F176A, failed to stimulate $\mathrm{Nb} 2$ proliferation, probably because of the low affinity for the PRL-BP. However, at much higher doses ( 1 and $10 \mathrm{ng} / \mathrm{ml}$, respectively), these two variants were able to stimulate $\mathrm{Nb} 2$ cellular proliferation. These data indicate that all these $\mathrm{HuGH}$ variants are biologically active, albeit with reduced potencies that are consistent with each analog's relative affinity for the HuPRL-BP.

Exogenous zinc augments secretion of $\mathrm{O}_{2}^{-}$by human neutrophils incubated with $H u G H$, but not HuPRL. Binding of HuGH to the HuPRL-R has recently been demonstrated to be zinc dependent (15). However, binding of HuGH to the HuGH-R and binding of HuPRL to the HuPRL-R are independent of zinc. Therefore, we tested the effect of exogenous zinc (from 25 to $100 \mu \mathrm{M}$ ) on the priming of human neutrophils induced by either HuGH or HuPRL. As shown in Fig. 6, $\mathrm{HuGH}$ at $25 \mathrm{ng} / \mathrm{ml}$ was unable to induce priming in the absence of additional zinc. Exogenous zinc (from 25 to $100 \mu \mathrm{M}$ ) by itself had no effect on control neutrophils. However, exogenous zinc significantly boosted $\mathrm{HuGH}(25 \mathrm{ng} / \mathrm{ml})$-mediated enhancement in $\mathrm{O}_{2}^{-}$secretion to a level comparable to that of human neutrophils treated with a 10 -fold higher concentration $(250 \mathrm{ng} / \mathrm{ml})$. Priming neutrophils with $\mathrm{HuGH}$ at $250 \mathrm{ng} / \mathrm{ml}$ was independent of exogenous zinc. Zinc did not alter the secretion of $\mathrm{O}_{2}^{-}$by human neutrophils that were primed with HuPRL and triggered with PMA (data not shown). Since the level of zinc plays a critical role in mediating the binding of HuGH to the HuPRL-R, but not of HuGH to the HuGH-R or of HuPRL to the HuPRL-R (15), these data reinforce the previous conclusion that $\mathrm{HuGH}$ binds to the HuPRL-R to augment the secretion of $\mathrm{O}_{2}^{-}$by human neutrophils.

\section{Discussion}

In this report, four lines of evidence suggest that the relevant receptor by which $\mathrm{HuGH}$ augments the secretion of $\mathrm{O}_{2}^{-}$by human neutrophils is primarily the HuPRL-R, not the HuGHR. (a) Recombinant HuPRL greatly augments the secretion of

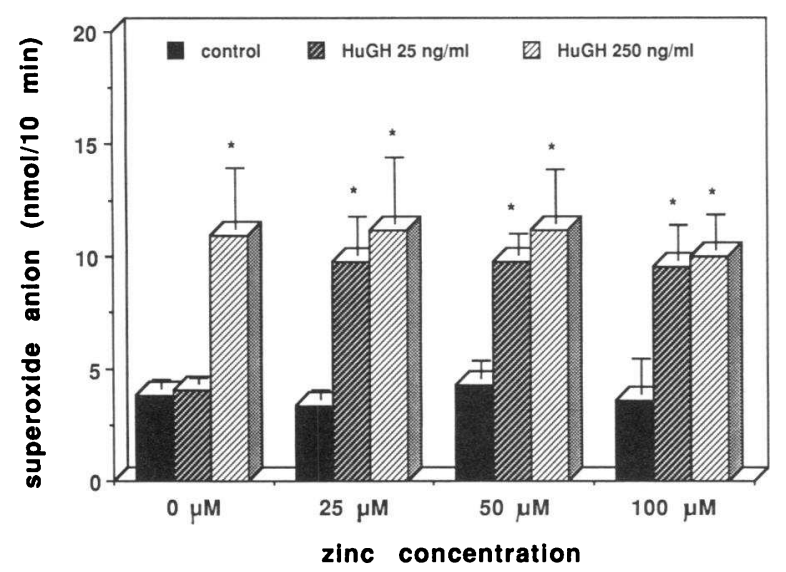

Figure 6. Exogenous zinc potentiates the capability of HuGH to aug ment the secretion of $\mathrm{O}_{2}^{-}$by human neutrophils. $\mathrm{HuGH}$ at $25 \mathrm{ng} / \mathrm{ml}$ did not augment $\mathrm{O}_{2}^{-}$secretion of neutrophils in the absence of exogenous zinc $\left(\mathrm{ZnCl}_{2}\right)$. Zinc at 25 to $100 \mu \mathrm{M}$ did not affect $\mathrm{O}_{2}^{-}$secretion by neutrophils incubated in medium only, but boosted the priming with $\mathrm{HuGH}$ at $25 \mathrm{ng} / \mathrm{ml}$ to a level comparable to that of $\mathrm{HuGH}$ at $250 \mathrm{ng} / \mathrm{ml} \mathrm{(*}, P<0.05, n=3)$. Priming at $250 \mathrm{ng} / \mathrm{ml}$ of $\mathrm{HuGH}$ was independent of exogenous zinc.
$\mathrm{O}_{2}^{-}$by human neutrophils. However, recombinant $\mathrm{GH}$ molecules derived from two nonprimate species that do not bind to the HuPRL-R are unable to prime human neutrophils even though they are capable of enhancing the secretion of $\mathrm{O}_{2}^{-}$by species-specific neutrophils. (b) A MAb directed against either the HuGH-R or HuPRL-R was used. Only the antibody against the HuPRL-R totally blocked the priming of human neutrophils incubated with either HuPRL or HuGH. (c) Alanine- and homologue-scanning mutagenesis were used to generate a set of predesigned HuGH variants that differentially bind to either the HuGH-R or HuPRL-R. The variant that did not bind either receptor was unable to augment the secretion of $\mathrm{O}_{2}^{-}$ by human neutrophils, which indicates that the priming of human neutrophils by $\mathrm{HuGH}$ or HuPRL requires a functional ligand-receptor interaction. More importantly, the variant that bound preferentially to the HuPRL-R was able to enhance $\mathrm{O}_{2}^{-}$secretion by human neutrophils whereas the response induced by the HuGH-R specific analog was much reduced. $(d)$ Exogenous zinc was able to augment the respiratory burst of human neutrophils when $\mathrm{HuGH}$, but not HuPRL, was used. Since zinc is required for binding of HuGH to the HuPRL-R, but not for HuGH binding to the HuGH-R or for HuPRL binding to the HuPRL-R, these data also argue that the HuPRL-R is the relevant receptor for priming human neutrophils for $\mathrm{O}_{2}^{-}$secretion.

The conclusion that the HuPRL-R is primarily responsible for HuGH-mediated priming of human neutrophils for $\mathrm{O}_{2}^{-}$secretion is similar to the finding that HuGH stimulates rat thymulin production by binding to the PRL-R rather than to the $\mathrm{GH}-\mathrm{R}$ on rat thymic epithelial cells (9). Unlike $\mathrm{HuGH}$, rat GH does not bind to the PRL-R and fails to exert a PRL-R-mediated stimulatory effect on thymulin production. However, the ability of $\mathrm{GH}$ to prime neutrophils for $\mathrm{O}_{2}^{-}$secretion may be conserved in a variety of species ( 23 and Fig. 2). For example, neither porcine nor bovine GH bind to the PRL-R but they prime porcine and bovine neutrophils, respectively, for $\mathrm{O}_{2}^{-}$secretion, suggesting that the GH-R mediates the priming of both porcine and bovine neutrophils by their own $\mathrm{GH}$. Although HuGH binds to the HuGH-R, data in our report suggest a unique feature of the human neutrophil is that the PRL-R is primarily involved in modulating this HuGH-mediated functional activation of neutrophils. Accordingly, our data imply that the GH-R is of reduced importance on human neutrophils or that $\mathrm{HuGH}$ is preferentially directed to the HuPRL-R due to the inevitable presence of zinc. There are no reports on the expression of either GH-R or PRL-R on neutrophils, although receptors for both hormones have been detected on human lymphocytes $(29,31,32)$. Our preliminary results suggest the presence of both mRNAs for the GH-R and for the PRL-R in human neutrophils, as assessed by the polymerase chain reaction, RNA-RNA-hybridization techniques, and the presence of the PRL-R, but not the GH-R, in neutrophil membrane extracts as determined by Western blot analysis (data not shown). The expression of a functional HuGH-R on human neutrophils may therefore be subject to post-translational regulation. It is also important that both PRL- (33-36) and GH- (37-39) like molecules are synthesized by lymphoid cells and that PRL augments a number of immune responses such as contact sensitivity reactions $(4,40)$, synthesis of interferon- $\gamma(41)$ and expression of receptors for interleukin 2 (42).

Chimeric molecules or variants of HuGH that are generated by site-directed mutagenesis have proven to be powerful tools for studying ligand-receptor interactions. Using this ap- 
proach, our results not only couple ligand-receptor binding with direct functional activation of human neutrophils, but they also suggest the exclusiveness of the PRL-R in mediating the effect of HuGH in this system. Another report demonstrated that a $\mathrm{GH}$ variant generated by a similar technique acts as a $\mathrm{GH}$ antagonist which suppresses growth of transgenic mice by blocking the GH-R without stimulating release of its physiological mediator, IGF-I (43). Therefore, in addition to data on the receptor-binding affinity of these variants, measurement of functional activities using biological assays can provide important clues about understanding the relevant events that occur after ligand-receptor interaction.

Like HuGH, human placental lactogen (PL) binds to the PRL-R (44) and exerts lactogenic effects on target cells. PL is a glycoprotein and the oligosaccharide components of PL are important functional determinants (45). Enzymatic deglycosylation of PL can be used to differentiate between somatogenic and lactogenic receptor binding and biological activities of PL. Unlike PL, GH is not naturally glycosylated, thus the approach for determining PL's somatogenic or lactogenic effect is not applicable to HuGH. Recently, it has been demonstrated that zinc plays a critical role in determining HuGH's lactogenic-receptor binding activity (15). By adding or removing zinc, differential receptor binding of $\mathrm{HuGH}$ to the HuPRL-R and biological activity can be easily determined. Our finding that exogenous zinc potentiates $\mathrm{HuGH}$-mediated priming of neutrophils for an enhancement of $\mathrm{O}_{2}^{-}$secretion further links receptor-binding with a direct functional activation of target cells and demonstrates an important role of zinc in mediating this particular event. There are considerable data which demonstrate that zinc plays a critical role in several physiological systems and that zinc affects many functions of both the peripheral nerves $(46,47)$ and cells of the immune system, including neutrophils, and it is now apparent that zinc deficiency suppresses several components of the immune system (48-52). The present report is the first to show that by mediating the binding of $\mathrm{HuGH}$ to the PRL-R, zinc augments the secretion of $\mathrm{O}_{2}^{-}$by human neutrophils incubated with $\mathrm{HuGH}$. Since both the GH-R and PRL-R are homologous to the receptors of the cytokine receptor gene superfamily (53-55), zinc may also be involved in mediating other cytokine actions by ligand-receptor binding.

\section{Acknowledgments}

The authors thank Dr. N. Paris and Dr. L. Mercier, Laboratoire de Recherches de Physiologie Vegetale, 49045 Angers-Cedex 01, France, who supplied limited quantities of recombinant HuPRL to initiate these studies.

This research was supported in part by grants to Keith W. Kelley from the National Institutes of Health AG06246 and the United States Department of Agriculture 89-37265-4536.

\section{References}

1. Hughes, J. P., and H. G. Friesen. 1985. The nature and regulation of the receptors for pituitary growth hormone. Annu. Rev. Physiol. 47:469-482.

2. Isaksson, O., S. Eclen, and J. O. Jansson. 1985. Mode of action of pituitary growth hormone on target cells. Annu. Rev. Physiol. 47:483-499.

3. Chawla, R. K., J. S. Parks, and D. Rudman. 1983. Structural variants of human growth hormone: biochemical, genetic, and clinical aspects. Annu. Rev. Med. 34:519-547.

4. Nagy, E., I. Berczi, and H. G. Friesen. 1983. Regulation of immunity in rats by lactogenic and growth hormones. Acta Endocrinol. 102:351-357.

5. Kelley, K. W. 1989. Growth hormone, lymphocytes and macrophages Biochem. Pharmacol. 38:705-713.

6. Berczi, I., E. Nagy, S. M. DeToledo, R. J. Matusik, and H. G. Friesen. 1991
Pituitary hormones regulate c-myc and DNA synthesis in lymphoid tissue. $J$ Immunol. 146:2201-2206.

7. Kelly, P. A., B. I. Posner, T. Tsushima, and H. G. Friesen. 1974. Studies of insulin, growth hormone and prolactin binding: ontogenesis, effects of sex and pregnancy. Endocrinology. 95:532-539.

8. Posner, B. I., P. A. Kelly, R. P. C. Shiu, and H. G. Friesen. 1974. Studies of insulin, growth hormone and prolactin binding: tissue distribution, species variation and characterization. Endocrinology. 95:521-531.

9. Dardenne, M., W. Salvino, W., M. C. Gagnerault, T. Itoh, and J. F. Bach. 1989. Neuroendocrine control of thymic hormonal production. I. Prolactin stimulates in vivo and in vitro the production of thymulin by human and murine thymic epithelial cells. Endocrinology. 125:3-11.

10. Leung, D. W., S. A. Spencer, G. Cachianes, R. G. Hammond, C. Collins, W. J. Henzel, R. Barnard, M. J. Water, and W. I. Wood. 1987. Growth hormone receptor and serum binding protein: purification, cloning and expression. Nature (Lond.). 330:537-543.

11. Fuh, G., M. G. Mulkerrin, S. Bass, N. MacFarland, M. Brochier, J. H. Bourell, D. R. Light, and J. A. Wells. 1990. The human growth hormone receptor. Secretion from Escherichia coli and disulfide bonding pattern of the extracellular binding domain. J. Biol. Chem. 265:3111-3115.

12. Boutin, J. M., M. Edery, M. Shirota, C. Jolicoeur, L. Lesueur, S. Ali, D. Gould, J. Djiane, and P. A. Kelly. 1989. Identification of a cDNA encoding a long form of prolactin receptor in human hepatoma and breast cancer cells. $\mathrm{Mol}$. Endocrinol. 3:1455-1461.

13. Boutin, J. M., C. Jolicoeur, H. Okamura, J. Gagnon, M. Edery, M. Shirota, D. Banville, I. Dusanter-Fourt, J. Djiane, and P. A. Kelly. 1988. Cloning and expression of the rat prolactin receptor, a member of the growth hormone/prolactin receptor gene family. Cell. 53:69-77.

14. Freemark, M., M. Comer, G. Korner, and S. Handwerger. 1987. A unique placental lactogen receptor. Implications for fetal growth. Endocrinology. 120:1865-1872.

15. Cunningham, B. C., S. Bass, G. Fuh, G., and J. A. Wells. 1990. Zinc mediation of the binding of human growth hormone to the human prolactin receptor. Science (Wash. DC). 250:1709-1712.

16. Cunningham, B. C., D. J. Henner, and J. A. Wells. 1990. Engineering human prolactin to bind to the human growth hormone receptor. Science (Wash. DC). 247:1461-1465.

17. Cunningham, B. C., P. Jhurani, P. Ng, and J. A. Wells. 1989. Receptor and antibody epitopes in human growth hormone identified by homolog-scanning mutagenesis. Science (Wash. DC). 243:1330-1336.

18. Cunningham, B. C., and J. A. Wells. 1991. Rational design of receptorspecific variants of human growth hormone. Proc. Natl. Acad. Sci. USA. 88:3407-3411.

19. Edwards, C. K. III, L. M. Yunger, R. M. Lorence, R. Dantzer, and K. W. Kelley. 1991. The pituitary gland is required for protection against lethal effects of Salmonella typhimurium. Proc. Natl. Acad. Sci. USA. 88:2274-2277.

20. Edwards, C. K. III, R. M. Lorence, D. M. Dunham, S. Arkins, L. M. Yunger, J. A. Greager, R. J. Walter, R. Dantzer, and K. W. Kelley. 1991. Hypophysectomy inhibits the synthesis of tumor necrosis factor $\alpha$ by rat macrophages: Partial restoration by exogenous growth hormone or interferon $\gamma$. Endocrinology. 128:989-996.

21. Edwards, C. K. III, S. M. Ghiasuddin, J. M., Schepper, L. M., Yunger, and K. W. Kelley. 1988. A newly defined property of somatotropin: priming of macrophages for production of superoxide anion. Science (Wash. DC). 239:769-771.

22. Edwards, C. K. III, J. M. Schepper, L. M., Yunger, and K. W. Kelley. 1988. Somatotropin and prolactin enhance respiratory burst activity of macrophages. Ann. N.Y. Acad. Sci. 540:698-699.

23. Fu, Y. K., S. Arkins, B. S. Wang, and K. W. Kelley. 1991. A novel role of growth hormone and insulin-like growth factor-I: priming neutrophils for superoxide anion secretion. J. Immunol. 146:1602-1608.

24. Carlson, G. P., and J. J. Kaneko. 1972. Isolation of leukocytes from bovine peripheral blood. Proc. Soc. Exp. Biol. Med. 142:853-856.

25. Barnard, R., P. G. Bundesen, D. B. Rylatt, and M. J. Waters. 1984. Monoclonal antibodies to the rabbit liver growth hormone receptor: production and characterization. Endocrinology. 115:1805-1813.

26. Cohen, H. J., and M. E. Chovaniec. 1978. Superoxide generation by digitonin-stimulated guinea pig granulocytes. A basis for a continuous assay for monitoring superoxide production and for the study of the action of the generating system. J. Clin. Invest. 61:1081-1087.

27. Tanaka, T., R. P. C. Shiu, P. W. Gout, C. T. Beer, R. L. Nobel, and H. G. Friesen. 1980. A new sensitive and specific bioassay for lactogenic hormones: measurement of prolactin and growth hormone in human serum. J. Clin. Endocrinol. Metab. 51:1058-1063.

28. SAS. 1985. In SAS User's Guide. Statistics. SAS Institute, Cary, NC.

29. Lesniak, M. A., P. Gorden, J. Roth, and J. R. Gavin III. 1974. Binding of ${ }^{125} \mathrm{I}$-human growth hormone to specific receptors in human cultured lymphocytes: characterization of the interaction and a sensitive radioreceptor assay. $J$. Biol. Chem. 249:1661-1667.

30. Kurtz, A., W. Hartl, W. Jelkmann, J. Zapf, and C. Bauer. 1985. Activity in fetal bovine serum that stimulates erythroid colony formation in fetal mouse livers is insulin-like growth factor I. J. Clin. Invest. 76:1643-1648. 
31. Russell, D. H., L. Matrisian, R. Kibler, D. F. Larson, B. Poulos, and B. E. Magun. 1984. Prolactin receptors on human lymphocytes and their modulation by cyclosporine. Biochem. Biophys. Res. Commun. 121:899-906.

32. Clevenger, C. V., D. H. Russell, P. M. Appasamy, and M. B. Prystowsky. 1990. Regulation of interleukin 2-driven T-lymphocyte proliferation by prolactin. Proc. Natl. Acad. Sci. USA. 87:6460-6464.

33. Kenner, J. R., J. W. Holaday, E. W. Bernton, and P. Smith. F. 1990. Prolactin-like protein in murine splenocytes. Morphological and biochemical evidence. Prog. Neuroendocrinimmunol. 3:188-195.

34. Montgomery, D. W., J. A. LeFevre, E. D. Ulrich, C. R. Adamson, and C. F. Zukoski. 1990. Identification of prolactin-like proteins synthesized by normal murine lymphocytes. Endocrinology. 127:2601-2603.

35. Montgomery, D. W., G. N. Shah, C. F. Zukoski, A. R. Buckley, A. R., T. Pacholczyk, and D. H. Russell. 1987. Concanavalin A treated murine splenocytes produce a factor with prolactin-like bioactivity and immunoreactivity. Biochem. Biophys. Res. Commun. 145:692-698.

36. Clevenger, C. V., S. W. Altmann, and M. B. Prystowsky. 1991. Requirement of nuclear prolactin for interleukin-2-stimulated proliferation of $\mathrm{T}$ lymphocytes. Science (Wash. DC). 253:77-79.

37. Weigent, D. A., J. B. Baxter, W. E. Wear, L. R. Smith, K. L. Bost, and J.E. Blalock. 1988. Production of immunoreactive growth hormone by mononuclear leukocytes. FASEB (Fed. Am. Soc. Exp. Biol.) J. 2:2812-2818.

38. Weigent, D. A., and J. E. Blalock. 1991. Production of growth hormone by rat mononuclear leukocytes. Cell. Immunol. 135:55-65.

39. Weigent, D. A., J. E. Blalock, and R. D. LeBoeuf. 1991. An antisense oligodeoxynucleotide to growth hormone messenger ribonucleic acid inhibits lymphocyte proliferation. Endocrinology. 128:2053-2057.

40. Nagy, E., and I. Berczi. 1991. Hypophysectomized rats depend on residual prolactin for survival. Endocrinology. 128:2776-2784.

41. Bernton, E. W., M. S. Meltzer, and J. W. Holaday. 1988. Suppression of macrophage action and T-lymphocyte function in hypoprolactinemic mice Science (Wash. DC). 239:401-404.

42. Mukherjee, P., A. M. Mastro, and W. C. Hymer. 1990. Prolactin induction of interleukin-2 receptors on rat splenic lymphocytes. Endocrinology. 126:88-94.

43. Chen, W. Y., D. C. Wight, T. E. Wagner, and J. J. Kopchick. 1990
Expression of a mutated bovine growth hormone gene suppresses growth of transgenic mice. Proc. Natl. Acad. Sci. USA. 87:5061-5065.

44. Loman, H. B., B. C. Cunningham, and J. A. Wells. 1991. Mutational analysis and protein engineering of receptor binding determinants in human placental lactogen. J. Biol. Chem. 266:10982-10988.

45. Byatt, J. C., J. K. Welply, R. M. Leimgruber, and R. J. Collier. 1990 Characterization of glycosylated bovine placental lactogen and the effect of enzymatic deglycosylation on receptor binding and biological activity. Endocrinology 127:1041-1049.

46. Hesse, G. W. 1979. Chronic zinc deficiency alters neuronal function of hippocampal mossy fibers. Science (Wash. DC). 205:1005-1006.

47. O'dell, B. L., J. Conley-Harrison, C. Besch-Williford, J. D. Browning, and D. O'Brien. 1990. Zinc status and peripheral nerve function in guinea pigs. $F A$ SEB (Fed. Am. Soc. Exp. Biol.) J. 4:2919-2922.

48. Winchurch, R. A. 1987. Zinc metabolism and immune aging. In Aging and the Immune Response. Cellular and Humoral Aspects. E. A. Goidl, editor. Marcel Dekker, Inc., New York. 295-308.

49. Winchurch, R. A., D. J. Thomas, W. H. Adler, and T. J. Lindsay. 1984. Supplemental zinc restores antibody formation in cultures of aged spleen cells. $J$. Immunol. 133:569-571.

50. Wirth, J. J., P. J. Fraker, and F. Kierszenbaum. 1984. Changes in the levels of marker expression by mononuclear phagocytes in zinc-deficient mice. J. Nutr. 113:1826-1833.

51. Wirth, J. J., P. J. Fraker, and F. Kierszenbaum. 1989. Zinc requirement for macrophage function: effect of zinc deficiency on uptake and killing of a protozoan parasite. Immunology. 68:114-119.

52. Vruwink, K. G., M. P. Fletcher, C. L. Keenn, M. S. Golub, A. G. Hendrickx, and M. E. Gershwin. 1991. Moderate zinc deficiency in rhesus monkeys: an intrinsic defect of neutrophil chemotaxis corrected by zinc repletion. J. Immunol. 146:244-249.

53. Bazan, J. F. 1990. Structural design and molecular evolution of a cytokine receptor superfamily. Proc. Natl. Acad. Sci. USA. 87:6934-6938.

54. Cosman, D., S. D. Layman, R. L. Idzerda, M. P. Beckmann, L. S. Park, R. G. Goodwin, and C. J. March. 1990. A new cytokine receptor superfamily. Trends Biochem. Sci. 15:265-270.

55. Patthy, L. 1990. Homology of a domain of the growth hormone/prolactin receptor family with type III modules of fibronectin. Cell. 61:13-14. 